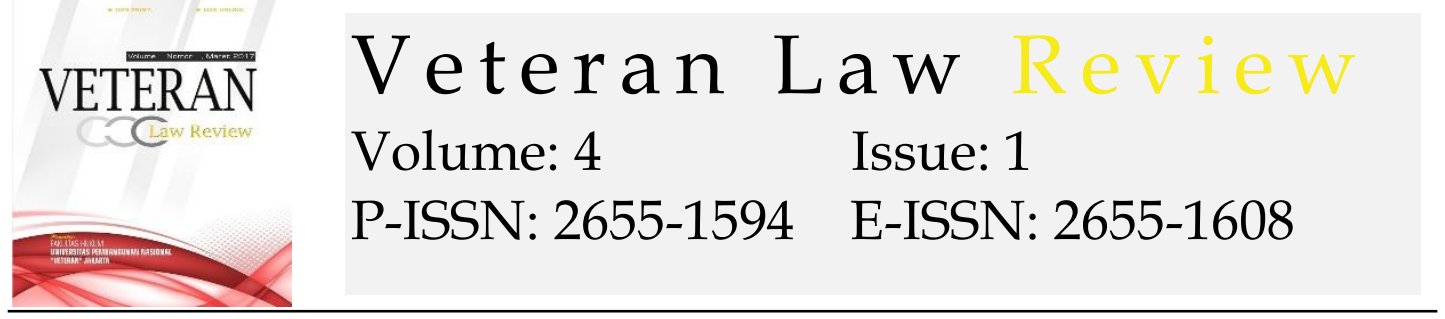

\title{
Plantation Regulation In The Palm Industry Sector In The Omnibus Law Of Employment Creation (Cipta Kerja)
}

\section{Heru Sugiyono1, Imam Haryanto ${ }^{2}$}

${ }^{1}$ Faculty of Law, Pembangunan Nasional "Veteran" University, E-mail: herusugiyono@upnvj.ac.id

${ }^{2}$ Faculty of Law, Pembangunan Nasional "Veteran" University, E-mail: haryanto81@gmail.com

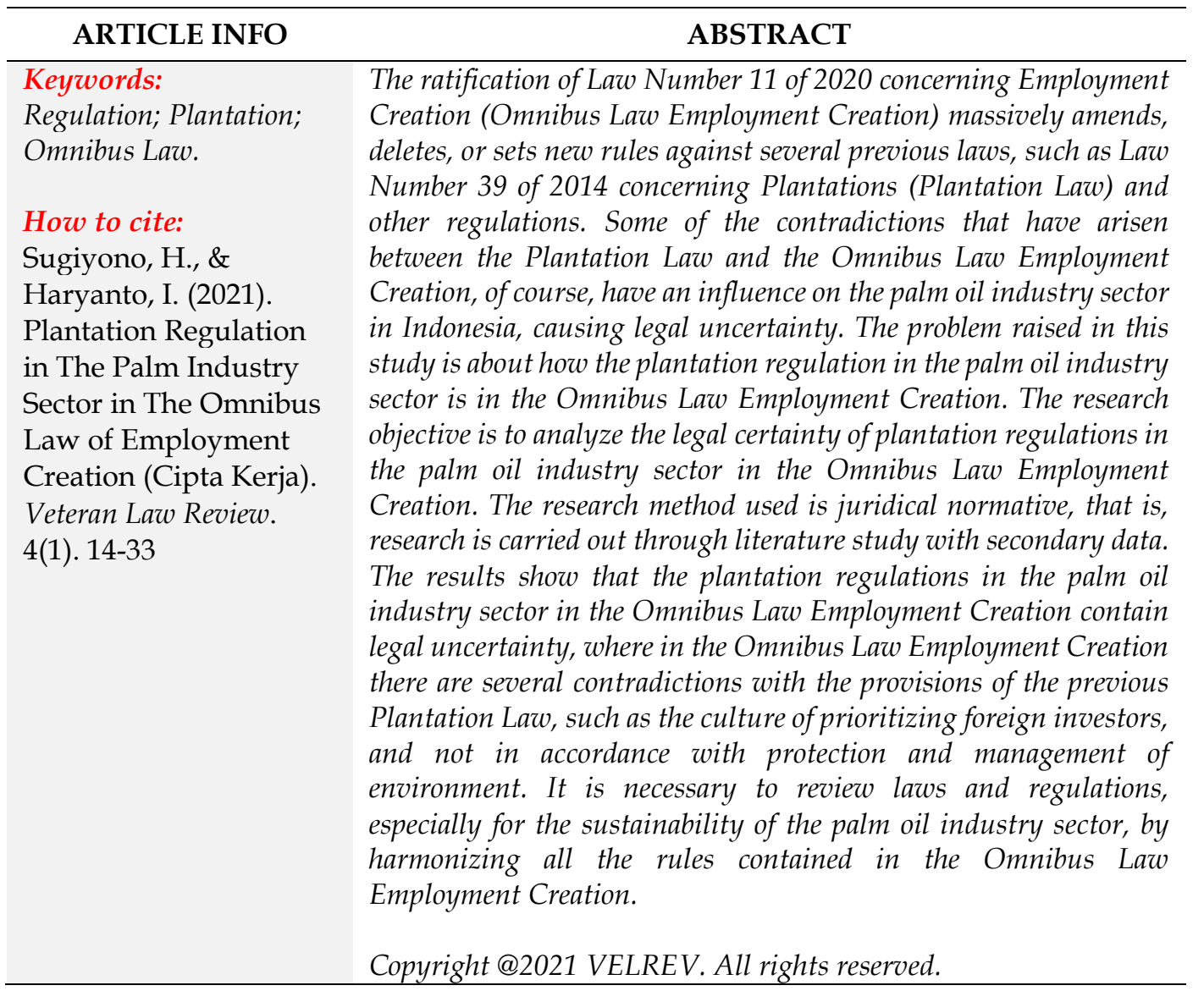

\section{Introduction}

Omnibus itself is translated into Indonesian as "a passenger bus, a collection of essays, or that covers many things"1. Omnibus has a relationship or deals with many objects or items at once, including many things or have multiple purposes ${ }^{2}$. Omnibus law is the practice of drafting laws and regulations that have been adopted by countries with common law or anglo saxon principles,

1 Google.com. Translation from Google Translate. English to Indonesia. Retrieved on February 11 th 2021

2 Garner, Bryan A. (Ed.). (2009). Black's Law Dictionary. (pp. 3452). West Publishing Co. 
such as America, England, Canada, the Philippines, and others. The process of creating an omnibus law product is called omnibus legislating and the product is called an omnibus bill ${ }^{3}$. Jimly Asshiddiqie provides a definition of the Omnibus Law, which is a law that covers a lot of material or all other Law materials that are interrelated, either directly or indirectly. This kind of practice is not uncommon in civil law but has been seen as good and continues to be today ${ }^{4}$. Thus, the omnibus law packages or combines several statutory regulations into one, its existence functions to change several articles contained in statutory regulations at once in other words the omnibus method is to simplify a rule that is too many and less harmonized properly between one another ${ }^{5}$.

The effort to harmonize is stated in Law Number 11 of 2020 concerning Employment Creation (hereinafter referred to as the Omnibus Law Employment Creation) itself, based on the scope of: "a. enhancing the investment ecosystem and business activities; b. employment; c. convenience, protection, and empowerment of Cooperatives and Micro, Small and Medium Enterprises (UMKM); d. ease of doing business; e. research and innovation support; f. land acquisition; g. economic area; h. Central Government investment and acceleration of national strategic projects; i. implementation of government administration; and j. imposition of sanctions"6. So that with the ratification of the Omnibus Law Employment Creation en masse to change, delete, or stipulate new rules for several articles contained in approximately 79 (seventy nine) of the previous laws ${ }^{7}$, in 79 th of these laws were divided into 11 clusters that were arranged to absorb a lot of labor, ease of doing business and adjustment of regulatory aspects related to ease of doing business, so that laws and regulations that become obstacles to ease of doing business will be simplified through the omnibus law ${ }^{8}$.

Harmonization of a law is a cool breeze that sounds very beneficial to all people in Indonesia, as well as when they hear about the noble purpose of the Omnibus Law Employment Creation to improve the investment ecosystem and business activities; increased protection and health of workers; convenience, empowerment, and protection of cooperatives and SMEs; and

$3 \quad$ Academic Script of Omnibus Bills Employment Creation. (2020). (pp. 24).

$4 \quad$ A., Ahmad U., L., Sakti, P., Ditta C. (2020). Architecture of Application of Omnibus Law through Transplantation of National Laws of Law Establishment. Journal Ilmiah Kebijakan Hukum. (pp. 4).

$5 \quad$ A., Risca, R., Cipta I. L. (2020). Omnibus Law in Indonesia: Is That the Right Strategy? Proceedings of International Conference on Law, Economics and Health. (pp. 180).

$6 \quad$ Article 4. Law of the Republic of Indonesia Number 11 of 2020 concerning Employment Creation. State Gazette of the Republic of Indonesia of 2020 Number 245. Supplement to State Gazette of the Republic of Indonesia Number 6573.

$7 \quad$ BBC News Indonesia. (2020). The contents of the Omnibus Law: The final document of the Job Creation Law cannot yet be accessed by the public experts are concerned about the 'entry of contraband articles'.

$8 \quad$ Y., Muhammad. (Ed.). (2020). Get to know the "Omnibus Law" method. 
increasing government investment and accelerating strategic projects ${ }^{9}$. With the simplification of regulations that are too long and complicated, the omnibus law is a way to convince business actors, especially in the international sphere, that a more predictable regulatory system has been established, a better business climate will increase competitiveness, increase more investment, and Employment opportunities will increase ${ }^{10}$. After describing some of the advantages of implementing the Omnibus Law, Abbe R. Gluck, et.al., stated that the Omnibus Law is an effort to harmonize every branch of law into one unit, so that the Omnibus Law has very long, complex, and is an effective way of bringing together many stakeholders (both legislative and executive), but the existence of the Omnibus Law sometimes becomes a challenge to the generally accepted doctrine of legislative perfection, because often the Omnibus Law is created too long and the arrangement is very messy, and sometimes there are linguistic inconsistency that is less tolerable, the omnibus law itself is often out of date due to years of production, sometimes there is no treatise on the making of the Omnibus Law, because many go through the usual stages of the legislative process. have been done $^{11}$. Then Louis Massicotte, stated that the omnibus bills, became a demand for improvement or attention, because they caused confusion and disturbance in the mind of the legislature by mixing inappropriate subjects (laws and regulations), the ratification of the omnibus law was forced to protect evil interests, because of the passage of one law. would be very visible and preventable ${ }^{12}$.

The implementation of the Omnibus Law itself covers various aspects including the palm oil industry sector, some expect positive things, it is hoped that the presence of the Employment Creation Law or Omnibus Law provides solutions to problems in the management and supervision of the palm oil industry, this momentum was manifested as an effort to simplify regulations and permits for palm oil. then this regulation seeks to facilitate investment in Indonesia ${ }^{13}$. In addition, there is hope from the palm oil farmers that the passing of this law can improve the fate of the Riau oil palm farmers ${ }^{14}$. Business and investment licensing has become simpler and faster; illegal fees and corruption are cut by integrating the licensing process in the online single submission system (OSS); business and investment activities are facilitated; investment activities in special economic zones, free trade areas and free ports are made easy; the establishment of a sovereign wealth fund whose function

9 Explanation of Part I General. Law of the Republic of Indonesia Number 11 of 2020 concerning Employment Creation. State Gazette of the Republic of Indonesia of 2020 Number 245. Supplement to State Gazette of the Republic of Indonesia Number 6573. American Chamber of Commerce in Indonesia. Peter S. L. (Ed.). (2020). Omnibus Bills: How do they Work?

11 G., Abbe R., O., Anne J., P., Rosa. (2015). Unorthodox Lawmaking, Unorthodox Rulemaking. Columbia Law Review. 115(7).

12 M., Louis. (2013). Omnibus Bills in Theory and Practice. Canadian Parliamentary Review. 36(1).

13 Kadin.id. (2020). The Palm Oil Industry Embraces the Implementation of Omnibus Law

14 Aziz, Abdul (Ed.). (2020). Omnibus Law Ratified, Happy Palm Oil Farmers. 
is to manage and place a number of and/or state assets and collaborate with third parties; protect and enhance the role of workers in supporting investment in Indonesia ${ }^{15}$. In addition, the Omnibus Law can also accelerate infrastructure due to monetary policies, inflation, accommodative fiscal policies; and the existence of apartment ownership licensing in Indonesia for foreigners will be a positive catalyst for property developers ${ }^{16}$.

There are also those who object to this Employment Creation Law, such as the management of oil palm due to the ratification of the Omnibus Law Employment Creation, which is getting worse, due to a settlement in the form of a whitening that has the potential for the licensing rules to be neglected, not transparent, leading to public losses and benefits to a group of parties ${ }^{17}$. Then, the Omnibus Law Employment Creation can trigger ecological damage ${ }^{18}$. Through the Employment Creation Law, the government provides permit facilities for parties who have violated plantation permits, and then make it easier for those offenders with a certain period of time to obtain permits ${ }^{19}$. In fact, according to the author, there are several provisions of articles in the Employment Creation Law that contain controversy.

Research on Omnibus Law Employment Creation has done a lot by the previous researcher, such as: (1) Rio who criticize for the issuance of Presidential Instruction Number 8 of 2018 concerning Postponement and evaluation of oil palm licensing as well as increased productivity of oil palm plantations (Inpres Moratorium) which explains the lack of clarity regarding licensing regulations which leads to legal uncertainty and contradicts Article 33 of the 1945 Constitution regarding the welfare of the people ${ }^{20}$, (2) Muamar and Utari explain that strict liability principle in environment law should not be obliged in the omnibus law employment creation, because it can threaten the success of the environment and provide opportunities for bad corporations to deforest 21 , (3) Eryan discuss about Inpres Moratorium that issued by the President in 2018 sparked controversy after the issuance of the Minister of Environment and Forestry's decision to issue forest release in this case that excessive forest release can pursue economic growth but pay less attention to

15 P., Clarissa F. \& T., Rizkianingtyas. (Ed.). (2020). President Jokowi Describes 6 Positive Impacts of the Omnibus Law on Work for the Business and Investment Climate.

16 Detik Finance. (2020). 3 Impact of the Foreign Analyst version of the Omnibus Law on Job Creation.

17 Infosawit.com. (2020). Improved Governance of Palm Oil "Lousy" Due to the Omnibus Law Employment Creation.

18 I., Muhammad (Ed.). (2020). Dissecting Concerns about Tenure of Palm Oil in the Job Creation Law. Money Kompas A., Lusia. (2020). Omnibus Law 'smooth road' Legalizes Violation of Oil Palm Investment in Forest Areas?

20 C., Rio. (2020). Evaluation of the Moratorium Policy on Postponing the Issuance of Permits on Oil Palm Plantations. Journal of Veritas et Justitia. (p. 1-22)

21 Muamar \& Utari, A. A. S. (2020). The Effect of the Elimination of the Principle of Strict Liability in the Omnibus Law Employment Creation on Massive Deforestation in Indonesia. Journal of Kerta Negara. (p. 1-12) 
the environment ${ }^{22}$, (4) The implementation Omnibus Law Employment Creation departs from the main principles of the Indonesia basic agrarian law (UUPA) and Article 33 Paragraph (3) of the 1945 Indonesian Constitution, namely the spirit to align economic growth goals through capitalistic land policies with the aim of equity through agrarian reforms will be increasingly difficult to materialize, because both capitalism and equity through reforms agrarianism has conflicting interests ${ }^{23}$.

The previous researchers did not discuss legal certainty, consistency, and clarity of norms contained in the Omnibus Law Employment Creation for the sustainability of the palm oil industry sector. Therefore, in this study, the authors are interested in raising the issue of how plantation regulations in the palm oil industry sector in the Omnibus Law Employment Creation. With this research, it is hoped that it can contribute to the preparation of plantation regulations in the palm oil industry sector in a just Omnibus Law Employment Creation.

\section{Method}

The research method that the author use is a type of normative legal research, namely research that collects and analyzes secondary data. ${ }^{24}$ Normative legal research examines law as norms or rules that apply in society. ${ }^{25}$ Normative legal research is aimed at written regulations, so that it is related to secondary data obtained through literature study. ${ }^{26}$ This research examines "theory, philosophy, comparison, composition, consistency, general explanation, explanation of each article of formality, the binding strength of laws, and legal language." 27

The author will examine the application of the Omnibus Law Employment Creation which is a norm in society from the aspect of legal certainty in the implementation of the palm oil business, because the analysis that is the focus of normative legal research is the applicable laws and regulations that are relevant to legal issues that are the focus of research. ${ }^{28}$ The secondary data that

22 E., Adrianus. (2019). From the Presidential Instruction for the Moratorium on Palm Oil to the Policy on Governance for the Palm Oil Industry, President Jokowi: A Case Study of the Issuance of Decree on the Release of PT Hardaya Inti Plantations in Buol, Central Sulawesi. Journal of Hukum Lingkungan Indonesia. (p. 1-18)

H., Dwi (2021). Agrarian Policy Problems in the Omnibus Law Employment Creation on the Performance of Agrarian Reform in Indonesia. Papers of IAIN Jember Lecturers at the Lecturer Periodic Discussion Seminar. (pp. 1-16) M., Peter M. (2009). Legal Research. (pp. 25). Kencana. Ishaq. (2017). Legal Research Methods and Writing Thesis, Thesis, and Dissertation. (pp. 66.) Alfabeta.

$26 \quad$ S., Soerjono \& M., Sri. (2001). Normative Legal Research A Brief Overview. (pp. 13). PT Raja Grafindo Persada.

27 S., Parta. Legal Research Methods, Definition, Kinds, Normative, Empirical, Approach, Data, Analysis, Experts.

28 B., Kornelius, \& A., Muhammad. (2020). Legal Research Methodology as an Instrument for Unraveling Contemporary Legal Problems. Journal of Gema Keadilan. (pp. 20-33) 
supports this research is divided into three types of sources of legal material. Primary legal materials constitute the prevailing statutory regulations, statutory minutes, judges' decisions. Secondary Legal Materials are publications related to law including books, journals, and comments on court award. ${ }^{29}$ Tertiary legal materials are legal dictionaries. ${ }^{30}$ This research uses

\section{Consistency of Land and Plantation Regulation in The Palm Industry Sector in The Omnibus Law Employment Creation}

Article 28D Paragraph (1) of the 1945 Constitution of the Republic of Indonesia states that "Everyone has the right to recognition, guarantee, protection, and legal certainty that is just and equal treatment before the law." The Indonesian Constitution itself provides legality regarding the right to legal certainty for everyone.

"A legal certainty arises, if it fulfills several things, namely: 31

1. If the type of action that is regulated is simple, stable, and does not involve big economic interests, it will create a greater aspect of legal certainty.

2. If the types of action to be regulated are complex, changeable and involve large economic interests: a. principles tend to govern with greater legal certainty than rules; $b$. binding principles in favor of non-binding rules tend to provide greater certainty than a single principle; $c$. Binding principles that support nonbinding rules provide more legal certainty if they are embedded in regulatory institutions that encourage mutual sensitivity."

Legal certainty and the substance of truth (correctness) appear in every legal system. Legal certainty is sometimes difficult to create in terms of the creation of a regulation, sometimes some regulations do not have inconsistencies in rules. ${ }^{32}$ Legal certainty is an effort to eliminate the obscurity, inconsistency and confusion of a legal system. Legal certainty consists of clarity, consistency, and comprehensive regulatory products. ${ }^{33}$ Legal certainty should not have multiple interpretations and law enforcement should not be arbitrary. ${ }^{34}$ Apart from that, legal certainty must be accompanied by the attachment of the principles of justice and benefit as a balanced and appropriate legal anatomy. ${ }^{35}$ Justice and benefit must be prioritized over legal certainty in order to create ideal law enforcement. ${ }^{36}$ The concept of rule of law is related to legal certainty

29 M., Peter M. Op. Cit., (pp. 141)

$30 \quad$ S., Bambang. (1998). Legal Research Methodology. (pp. 117). Raja Grafindo Persada.

31 B., John. (2002). Rules \& Principles: A Theory of Legal Certainty. SSRN Electronic Journal. (pp. 47)

A., Robert. (2015). Legal Certainty and Correctness. Ratio Juris. (pp. $444 \& 447$ ) S., Philip. (2013). The Legal and Political Legacy of Jeremy Bentham. Annual Review of Law and Social Science. (pp. 63) M., E. Fernando M. (2016). Legism, Legality and Legal Certainty. (pp. 154). Kencana Prenadamedia Group.

35 L., Heather (2000). Gustav Radbruch: An Extraordinary Legal Philosopher. Washington University Journal of Law \& Policy. (pp. 515)

36 M., Hasaziduhu. (2019). Law Enforcement in Indonesia according to the Aspects of Legal Certainty, Justice and Benefit. Journal of Warta. (pp. 10-11) 
and legal clarity. ${ }^{37}$ Legal certainty is an important aspect in the formation of a regulation. Consistency became one of factor decide law to be certain according to the Indonesian constitution. Therefore, the author want compare the omnibus law employment creation with plantation law, environmental law, and investment law, and other regulation that have similarities with oil palm plantation. through this comparison the researcher found several important points. The following is comparison between the Employment Creation Law and several laws or regulations that have been replaced in Omnibus Law Employment Creation, along with the author's interpretation of the Omnibus Law:

\subsection{Article 14 Plantation clusters Article 29 of the Omnibus Law Employment Creation}

In Article 14 of the Plantation Law, it is stated that the restrictions for the central government in setting maximum and minimum limits on land use for plantation businesses are from 9 restrictions become only 2 limitations, in Article 14 Plantation clusters Article 29 of the Omnibus Law Employment Creation only regulates the types of plants and the availability of suitable land based on agro-climatically. Meanwhile, capital; factory capacity; population density level; business development patterns; geographical conditions; technological development; and land use based on spatial function in accordance with statutory provisions in the spatial planning sector.

There is uncertainty, namely 'whether the seven things that are not regulated in the Plantation Clusters Work in Omnibus Law Employment Creation will be transferred in a government regulation or not as mandated in Article 14 Paragraph (3)?'. The legal consequences of the amendment to Article 14 Paragraph (3) of the Plantation Law that can result in the form of excessive convenience for plantation business actors because the central government only has two limitations in determining the maximum and minimum area limits for land use for plantation business, without the other seven points especially on geographic conditions, population density levels, and monitoring of land based on spatial functions in accordance with statutory provisions in the spatial planning sector, contrary to Article 2 of the Plantation Law letter $j$, plantations should be carried out based on the principle of preservation of environmental functions, in the explanation of the article states that "The operation of plantations must use facilities, infrastructure, procedures and technology that do not interfere with the function of the environment, be it biologically, mechanically, geologically, or chemically".

\subsection{Article 16 Plantation clusters Article 29 of the Omnibus Law Employment Creation} 37 R., Michel \& S., Andras. (Ed.). (2012). The Oxford Handbook of Comparative Constitutional
Law. (pp. 1047). Oxford University Press. 
In Article 16 of the Plantation Law, a plantation company is obliged to cultivate its plantation land, no later than 3 years after granting the status of land rights, plantation companies are obliged to cultivate plantation land for at least $30 \%$ of the area of land rights, and no later than 6 years after granting the status of rights to land. land that technically can be planted with plantation crops. In Article 16 of the Plantation Clusters Work Creation Law, changing it to 'a plantation company is obliged to cultivate plantation land no later than 2 years after granting the title to the land.' Even though these changes can cause legal uncertainty, because the plantation company is not given a clear regulation in the long term. The minimum time for 2 years must be what percentage of exploitation is carried out so that it is not subject to sanctions. In fact, this regulation seems to force plantation business actors to be able to cultivate all of the land within a period of two years, so that when within a period of two years there is still land that has not been cultivated, it will be taken by the government. This provision appears to be unfair because there is not enough time for the company to cultivate the entire land for up to a period of 6 years, as in Article 16 of the previous Plantation Law.

\subsection{Article 30 Plantation clusters Article 29 of the Omnibus Law Employment Creation}

Articles 30 and 31 of the Plantation Law are merged into Article 30 Plantation clusters Article 29 of the Omnibus Law Employment Creation and abolishing Article 31, regulating varieties resulting from breeding or introduction from abroad, before being circulated, they must first be released by the central government or launched by the owner of the variety. Varieties that have been released by the central government or launched by the owner of the variety can be produced and distributed, with the previous stipulation that they must fulfill the business license from the central government. Whereas in Article 31 of the Variety Plantation Law that can be produced and circulated, it must first be certified and labeled.

Of course, this provision can create confusion, because all technical matters are left to the central government, without a clear scope of regulations which are entitled to provide certification and labeling. In addition, it is feared that the transfer of all tasks to the central government will occur subjectively by giving certification and labeling by the government, and ignoring the derivative regulations that have been created as mandated by the Plantation Law.

\subsection{Article 39 Plantation clusters Article 29 of the Omnibus Law Employment Creation}

Article 39 of the Plantation Law provides regulations regarding plantation businesses that can be carried out in all areas of the Republic of Indonesia by domestic plantation business actors or foreign investors, foreign investors are obliged to be foreign legal entities or foreign individuals, then the foreign investors are only in conducting plantation business while cooperating with 
domestic plantation business actors by establishing an Indonesian legal entity. However, Article 39 of the Employment Creation Law provides discretion not only for foreign investors, but for foreign plantation business actors, with the mandate to comply with statutory regulations in the investment sector. Referring to Article 4 of Law Number 25 of 2007 concerning Investment (the Investment Law), it is said that the government provides equal treatment to every domestic and foreign investor while still paying attention to national interests, then Article 5 of the Investment Law explains that investment Foreign capital must be in the form of a limited liability company (Perseroan Terbatas) based on Indonesian law and domiciled in the territory of the Republic of Indonesia, unless otherwise stipulated by law.

Foreign business actors can operate plantations with due regard to national interests, however, the national interests themselves are not clearly regulated. The author is of the view that investment must prioritize domestic investors first. There are concerns that the provision of opportunities for foreign participation will lead to the elimination of (domestic) national plantation companies. In the end, it is not able to provide opportunities for development and provide strong protection to micro, small, and medium enterprises as in Article 4 of the Investment Law.

\subsection{Article 40 Plantation clusters Article 29 of the Omnibus Law Employment Creation}

Then in Article 40 Plantation clusters Article 29 of the Employment Creation Law regarding the transfer of ownership of plantation companies to foreign investors is carried out after obtaining approval from the central government, whereas in Article 40 of the Plantation Law the approval must be based on national interests, then approval is given authority to the minister.

The use of the term central government has caused confusion regarding the determination of the agency authorized to grant this approval, the use of the phrase central government, resulting in article 40 and other articles that impose rights on the central government to be considered by all parties from the level of the President and Vice President, Ministers, to all parties of state organs contained in the central government. With the elimination of the word national interest, it becomes a burden for the state to think about the sustainability of domestic plantation businesses or even plantation business actors at the UMKM level.

\subsection{Article 45 Plantation clusters Article 29 of the Omnibus Law Employment Creation}

Article 45 of the Plantation Law is abolished in the Plantation clusters of the Omnibus Law Employment Creation, even though this regulation is an important matter, namely in order to obtain approval for plantation exploitation, especially in the cultivation of plantation crops must meet 
requirements, have obtained environmental permits, conformity with regional spatial plans, and conformity with the plantation plan. Plantation cultivation business must have facilities, infrastructure, systems and means of controlling plant-disturbing organisms; For plantation product management businesses, a minimum of $20 \%$ of the total raw material required comes from self-cultivated plantations.

The legal consequence is that plantation exploitation in the form of plantation crop cultivation is not in accordance with the principles of environmental sustainability in Article 2 of the Plantation Law. If it is correlated with Law Number 32 of 2009 concerning Environmental Protection and Management (PPLH Law or Environment Law), in Article 1 Number 17, an Environmental Permit is "a permit given to every person who carries out a business and/or activity that is obliged to have an "Amdal or UKL-UPL" in the framework of environmental protection and management as a prerequisite for obtaining a business and/or activity license. "The business license is only granted if it has fulfilled the "Amdal and UKL-UPL", as an effort to protect and manage the environment. Article 1 Number 11 of the PPLH Law states that Amdal (Environmental Impact Analysis) stands for an analysis of environmental impacts, which is a "study of the significant impacts of a planned business and/or activity on the environment required for the decision-making process regarding the conduct of a business and/or activity". Continued in Article 1 Number 12 of the PPLH Law, UKL-UPL (Environmental Management Efforts and Environmental Monitoring Efforts) stands for environmental management efforts and environmental monitoring efforts, namely "management and monitoring of businesses and/or activities that do not have a significant impact on the environment required for the decision-making process regarding conducting business and/or activities. "

In Article 22 Cluster PPLH Article 1 Number 35 of the Omnibus Law Employment Creation states that environmental permits are not found, according to the author, it is replaced by the phrase environmental approval, namely "a decision on environmental feasibility or a statement of environmental management capability that has received approval from the central government or regional government." The meaning of environmental permit and environmental approval is very different, because in an environmental permit it requires Amdal and UKL-UPL as obligations that must be fulfilled to protect the environment, whereas in environmental approval it only contains environmental management without any protection of the environment.

\subsection{The Abolition of Article 50 of the Plantation Law}

Abolition of Article 50 of the Plantation Law which regulates "Ministers, governors and regents/mayors who are authorized to issue Plantation Business permits are prohibited from: a. issuing permits that are not in accordance with their designation; and/or b. issuing permits that are not in 
accordance with the terms and conditions of the laws and regulations. "The aboilition of this article is considered not to provide flexibility for regions to regulate the environment in their regions, because they are all regulated by the Central Government. Whereas in the Matrix of the Division of Concurrent Government Affairs between the Central Government and Provincial and District/City Governments in Law No. 23 of 2014 regarding Regional Government (Pemda Law), local governments still have some authority in both land affairs and the environment.

\subsection{Article 58 Plantation clusters Article 29 of the Omnibus Law Employment Creation}

Application of Article 58 of the Omnibus Law Employment Creation, which regulates the obligations for plantation companies that obtain business permits to cultivate all or part of their land originating from other use areas that are outside the right to cultivate; and/or areas originating from the release of forest areas, are obliged to facilitate the development of community gardens around $20 \%$ of the land area. The phrases 'licensing for cultivation' and 'about $20 \%$ ' are different from Article 58 of the Plantation Law, which states that plantation companies that have plantation business permits or plantation business permits for cultivation are obliged to facilitate the development of local community plantations, at least for an area of $20 \%$ of the total plantation area cultivated by plantation companies. In Article 58 of the Plantation Law the phrase is "plantation business license or plantation business permit for cultivation" and "the minimum is $20 \% . "$

Grammatically, there is a reduction in the regulation, namely the facilitation of community garden development, which previously for all types of plantation business, only became a certain type, namely plantation cultivation business and from a minimum of $20 \%$ to a maximum of $20 \%$. This is of course very detrimental to the surrounding community, because they are not given the opportunity to do business in the laws and regulations.

In the explanation of Article 58 of the Omnibus Law Employment Creation, "the obligation to facilitate the development of community plantations around the area of $20 \%$ is only shown to people who get land for plantations from other use areas that are outside the right to cultivate and/or originate from land areas from forest release. This obligation arises for plantation land which is sourced from state land", then continued "the obligation to facilitate community plantations is integrated with other obligations arising from the acquisition of plantation land, among others in the case of land originating from forest areas which imposes an obligation for $20 \%$ of the land to the community. and has been carried out, the obligation is completed." In other words, apart from Article 58 of the Plantation cluster, the Employment Creation Law changes the meaning of the article in the Plantation Law, the explanation of the article also provides another limitation, namely the obligation to facilitate this development only if it has been shown to the 
grower that he obtained plantation land from other use areas that are outside the HGU (Cultivation Rights), (not state land) and/or originating from forest release areas. So that if the land that is granted a license to a plantation business actor comes from HGU (Cultivation Rights) land, then there is no obligation for the plantation business actor to facilitate community plantation land.

As the Constitutional Court Decision No. 38 of 2015 which examines the material of the Plantation Law, states that $20 \%$ are built outside of land cultivated by companies or permits or HGU (Cultivation Rights). If it is analogized to the figure that $100 \%$ of the company cultivates an area of plantation land that has been permitted by the government and the company is obliged to facilitate $20 \%$ of the land area they own, to be $100 \%+20 \%$. The implementation of supervision of parties holding plantation permits by the government regarding its implementation for a period of three years has also not been included in the regulation. There is no sanction imposed by the government on the implementation of this article.

\subsection{Article 67 Plantation clusters Article 29 of the Omnibus Law Employment Creation}

Articles 67 and 68 of the Plantation Law oblige plantation business actors to maintain the preservation of environmental functions. The fulfillment of these obligations is in accordance with the provisions of laws and regulations, to maintain the preservation of environmental functions, before obtaining a plantation business license, plantation companies must prepare an Amdal (Environmental Impact Analysis) or effort environmental management and environmental monitoring efforts; must have analysis and risk management for those who use the results of genetic engineering; and must make a statement of commitment to provide adequate emergency response facilities, infrastructure and systems to cope with the occurrence of fires. If one of these requirements is not fulfilled, the application for a business license will be rejected. Then, if a plantation business license is obtained, the plantation business actor is obliged to apply an Amdal or environmental management efforts and environmental monitoring efforts; environmental risk analysis; and environmental monitoring. However, the existence of Article 67 Paragraphs 3 and 4 as well as Article 68 was deleted in the Plantation cluster of the Employment Creation Law, so that Article 67 only regulates business actors to be obliged to maintain the preservation of environmental functions, and further provisions are regulated in government regulations.

\subsection{Inconsistencies in Omnibus Law Employment Creation}

The existence of the Omnibus Law Employment Creation for the sustainability of oil palm through several article materials that the author describes, there are several contradictions between the new and the old laws. In fact, it is hoped that the existence of the Employment Creation Law can increase employment 
opportunities. However, in the Plantation Law sector or clusters itself, there are several points that prevent the creation of a sustainable palm oil industry. In the legal discipline, there is a scope of legal sciences, legal politics, and philosophy of law. The politics of law includes several activities of choosing values and establishing values. The existence of legal politics is very important, especially in paying attention to a guideline in society, which is always developing dynamically. These guidelines should aim to create a peaceful life between individuals, which consists of two things: 1) external order between individuals, 2) internal tranquility. These two things relate to: 1) providing certainty in law, 2) providing comparability in law, 3) spiritual and physical importance, 4) newness and permanence. The relationship created from the purpose of the guidelines with the task of providing legal certainty is aimed at order and the provision of legal equivalence is aimed at tranquility. 38

As a country that regulates human rights in the 1945 Constitution, human rights must be recognized by all parties. Recognition of human rights means that human rights must be protected, both against the actions of those in power and against individual actions that violate or reduce these rights. ${ }^{39}$ So that there is a burden on the state to protect the human rights of its citizens, one of which is stated in Article 28D of the 1945 Constitution of the Republic of Indonesia. In making a legal rule, a comprehensive understanding of law is needed as an integrated system which is very important, it is not allowed to see only one aspect or element in the creation of law. ${ }^{40}$ Including in this case the creation of the Omnibus Law Employment Creation, Important issues that need to be maintained in the Plantation Law such as the environment and domestic investment must be maintained. It should be necessary to refer to the MPR (People's Consultative Council) Decree No.I/MPR/1988, one of which discusses legal development as an effort to uphold justice, truth and order in an Indonesian constitutional state based on Pancasila and the 1945 Constitution, directed at increasing legal awareness, ensuring enforcement, services, and legal certainty. One of the efforts aimed at legal development is legal certainty. As a country with a continental European legal system, the main principle of this legal system is to gain binding power because it is in the form of regulations in the form of laws that are systematically arranged in codification. Legal certainty is the goal of law. ${ }^{41}$

Palm oil is a very potential feedstock for biofuels. The debate occurred regarding the emergence of the idea to expand the palm oil industry due to the emergence of a lot of demand for plantations ${ }^{42}$ that were created

\footnotetext{
38 P., Purnadi \& S., Soerjono. (1993). Regarding Legal Rule. (pp. 50-51). Citra Aditya Bakti.

39 S., Syahrizal, \& Rusdiyanta (Ed.). (2010) Implementation of Pancasila through Citizenship Education. (pp. 229). Graha Ilmu.

40 A., Jimly. (2015). Indonesian Constitution \& Constitutionalism. Second Edition. (pp. 308). Sinar Grafika.

41 Daliyo, J.B., et.al. (2001) Introduction to Indonesian Law. (pp. 36). Prenhallindo.

42 Corley, R.H.V. (2009). How much palm oil do we need? Environmental Science E Policy. (pp. 134)
} 
excessively which had serious consequences for biodiversity, climate change and natural resources. Based on the evidence found loss of carbon is damaging to the environment, threats to endangered and endemic species, air and water pollution. The majority of indigenous Indonesians suffer from the palm oil industry, the benefits are less than the losses, the surrounding communities are affected by burning for land clearing, loss of land rights, reduced natural resources that the communities rely on for their survival. ${ }^{43}$ Then the position of oil palm smallholders (not companies, such as MSMEs (UMKM) or even below them is very weak in facing changes in the international market. The challenges and limitations faced by smallholders have resulted in the low access of oil palm growers to become part of the global market supply chain. ${ }^{44}$

Economy, environment, and society are important keys for sustainable development, all of which must be considered, so that sustainability will last a long time. Regarding the environment, it is necessary to conserve natural resources which have a direct and significant indirect effect on the economy and public health. Ecosystems function best when they are in healthy conditions (with ecological integrity, connectivity and resilience). The pressure that comes from human and natural actions is caused by an unhealthy ecosystem. The oil palm industry is one of the consequences that causes damage to the ecosystem. Deforestation, loss of habitat for living things other than animals, can also damage biodiversity, disruption of the food chain, changes in soil conditions, water pollution, air pollution, loss of fertility of peat soils and other arable land, increase in carbon dioxide, forest fires, and natural disasters. The palm oil industry also has the potential to pollute land and water systems and release the greenhouse effect. 45

Various efforts are needed to address the sustainability of the palm oil industry which must continue to pay attention to the environment, as well as adequate regulations to regulate this, ${ }^{46}$ because the demand for palm oil has greatly increased. In addition, environmental certification is also capable of striving for the sustainability of the palm oil industry sector. ${ }^{47}$ The certification is called ISPO (Indonesia Sustainable Palm Oil), as a sustainable sustainability standard for the national palm oil industry based on Minister of Agriculture Regulation No.11/Permentan/OT.140/3/2015 concerning the Sustainable

43 P., Chelsea, P., Julia, and S., Stephanie. (2016). Ecological Impacts of Palm Oil Expansion in Indonesia. White Paper, The International Council on Clean Transportation. (pp. 14). H., Sakti. (2017). Challenges for the Sustainability of Smallholder Oil Palm Planters in Pelalawan District, Riau in Changing Global Trade. Masyarakat Indonesia. Journal of Ilmuilmu Sosial Indonesia. (pp. 59).

$45 \quad$ K., Rahima, R., Mohammad I. H., Moniruzzaman, M., \& Y., Zahira. (2017). Sustainable oil palm industry: The possibilities. Renewable and Sustainable Energy Reviews. (pp. 616)

46 W., David S. \& K., Lian P. (2010). Addressing the Threats to Biodiversity from Oil-palm Agriculture. Biodiversity and Conservation. (pp. 1006).

47 I., Fadhil M. (2018). Analysis of the Certification of Sustainable Palm Oil as an Instrument for Organizing Environmental Laws. Journal of Hukum Lingkungan. (pp. 71). 
Palm Oil Certification System in Indonesia. ${ }^{48}$ This ISPO is a match for the RSPO (Roundtable on Sustainable Palm Oil) belonging to the European Union which is voluntary, ISPO is mandatory to be fulfilled, contains legal sanctions, and has the principles of environmental sustainability and social justice, but there is a campaign from civil society that ISPO is still not Providing environmental sustainability and social justice, it must be anticipated by considering the input from the European Union Parliament which issued a palm oil resolution, so that Indonesia can export the palm oil industry back to the European Union, while still paying attention to environmental sustainability. ${ }^{49}$

This ISPO implementation needs to be carried out at the level of independent, non-company oil palm smallholders in the form of intensive assistance to provide awareness of the principles of sustainable plantations, farmers must also be helped to fulfill ISPO certification by stakeholders. ${ }^{50}$ In addition, it is necessary to socialize and increase the ease of obtaining superior plant seeds (legal) dissemination of best management practices, increasing the capacity of institutional and empowerment of smallholder plantations, and fostering environmental rejuvenation for independent farmers regarding the Palm Oil Program for the People (Prowitra). ${ }^{51}$ It is attempted by plantation companies through regulations that revert to the Plantation Law to provide assistance to facilitate $20 \%$ land outside of the HGU granted by the government, as a continuation of the government giving the company an obligation to foster and raise independent smallholders. ${ }^{52}$ Independent smallholders must also unite to form groups, and even form Village Unit Cooperatives, so that they can access capital financing from banks, so that they are expected to be able to compete with plantation companies. ${ }^{53}$

48 H., Sawarni, \& T., Hermawan, (2017). Palm Biodiesel Production Life Cycle Impact Assessment to Support the Sustainable Downstreaming of the Indonesian Palm Oil Industry. National Seminar of Inovasi \& Aplikasi Teknologi di Industri. (pp. 2) E., Erwiza. (2017). Di balik Keberlanjutan Sawit: AKtor, Aliansi dalam Ekonomi Politik Sertifikasi Uni Eropa. Masyarakat Indonesia. Journal of Behind Palm Oil Sustainability: Actors, Alliance in the Political Economy of EU Certification. Masyarakat Indonesia, Journal of Ilmu-ilmu Sosial Indonesia. (pp. 11).

50 D., Arya H., N., Fredian T., B., Baba, K., Rilus A., I., Yoyoh, I., Hana, M., Dyah I., R., Faris, H., Hilda N., R., Ade M. (2019). Readiness of Independent Oil Palm Smallholders in Implementing ISPO: Environmental Issues, Legality and Sustainability. Journal of Ilmu Lingkungan. (pp. 313).

51 A., Muhammad A., Amalia, R., Nurkhoiry, N. (2015). Palm Oil Program for the People (Prowitra) as an Effort to Increase Productivity, Empowerment, Sustainability and Welfare of Smallholder Oil Palm Planters. Proceeding of National Seminar "Perlindungan dan Pemberdayaan Pertanian dalam Rangka Pencapaian Kemandirian Pangan Nasional dan Peningkatan Kesejahteraan Petani". (pp. 321)

52 Ngadi \& N., Mita. (2017). Sustainability of Oil Palm Plantations in Indonesia and Development Prospects in Border Areas. Masyarakat Indonesia, Journal of Ilmu-ilmu Sosial Indonesia. (pp. 109)

53 N., Nurul L., Suharno, Al Jaksta, dan F., Anna. (2019). Status of the Sustainability of the Management of Sustainable Palm Oil Plantation in Trumon, Aceh Selatan District. Forum of Agribisnis (pp. 65) 
The sustainability of the palm oil industry also depends on the management of plantations related to ecology, economy, socio-culture, and infrastructure technology, as well as legal-institutional. Ecologists must regulate the number of dry months, intensity of pest and disease attacks on crops, conservation on sloping lands, and land suitability classes. The economy regulates the level of farmer empowerment and the profits of oil palm farmers' businesses. Socioculture regulates the average age of farmers and the last formal education taken by farmers. Technology-infrastructure regulates the desire of farmers to plant legal seeds (superior seeds) and standardizes the quality of the oil palm harvest. The law-institution regulates the participation of farmers in groups and the existence of these groups. ${ }^{54}$

Legal certainty will be difficult to occur, if the regulations made contain disharmony. The Omnibus Law is a set of laws that are regulated in one Act. The Omnibus Law Employment Creation which was passed in the form of the Omnibus Law has not fulfilled the aspect of legal uncertainty because besides there are contradictions, especially with the previous Plantation Law, such as the impression that foreign investors prioritize, are not in accordance with environmental protection and management. Even though these aspects are contained in the Indonesian constitution. The constitution is the basic law, basic norms, and at the same time the highest position in the state system. ${ }^{55}$

The use of land rights in the form of Cultivation Rights (HGU), is state-owned land that is embedded in these rights, the Constitution and Basic agrarian law (UUPA), namely the use of such cultivation rights must be solely for the benefit of the communities around the land. Relations between the State and the earth, water and space, including the natural resources contained therein, as the organization of the power of all the people, the state acts in its position as the Power and Officer of the Indonesian Nation. ${ }^{56}$ In the interests of the surrounding communities who are within the scope of the HGU for plantation companies that have obtained permits, the government should have formulated Article 58 of the Plantation cluster Article 29 of the Employment Law Act, which is fairer, and provides a portion of land for the people as stated in Article 58 of the previous Plantation Law and the decision of the constitutional court No. 38 of 2015.

According to the authors, the sustainability of the palm oil industry has many elaborating dimensions, such as environmental aspects, the welfare of the community around oil palm plantations, the operation of oil palm plantations until they become commercialized products, investment, and other aspects.

54 Iskandar, U., Satria P., \& B., Muhammad F. (2018). Analysis of the Sustainability of Management of Nucleus-Plasma Pattern Oil Palm Plantations at PT Bio Nusantara Teknologi Bengkulu Tengah Regency. Naturalis, Journal of Penelitian Pengelolaan Sumber Daya Alam dan Lingkungan. (pp. 8)

55 A., Jimly. (2015). Introduction to Constitutional Law. (pp. 161). Rajawali Pers.

56 H., Boedi. (2008). Indonesian Agrarian Law. Revisited Edition. (pp. 232). Djambatan. 
The probability of the entry of investment both at national and international scale will increase in the palm oil sector, but the certainty of regulation for environmental sustainability can endanger Indonesia's nature, the impact caused by land acquisition in forests (natural damage), the community around the plantations does not pay attention because of $20 \%$ of the land which is built with narrower regulatory provisions, the community is less likely to be facilitated by plantation land. Investment must also be avoided from the increase of foreign investors, compared to national investors, then the entry or permission of foreign companies to manage plantation land is feared by MSMEs (UMKM) in the palm oil sector that can be eliminated. Because the increase in investment is not in line with the negative impacts it has, it is necessary to reorganize the plantation regulations in the palm oil sector in the Omnibus law Employment Creation.

\section{Conclusion}

A broad discussion aspect is needed regarding the sustainability of the palm oil industry, because in terms of investment, the Omnibus Law Employment Creation in the Plantation cluster provides an opportunity for foreign companies to carry out plantation exploitation which has an impact on the death of MSMEs (UMKM) or independent smallholders who work on oil palm plantations independently, then from an environmental perspective. Many permits have been eliminated, resulting in the possibility of ecological damage, in terms of land regulations, the granting of facilitation to the surrounding community for the HGU that has been permitted by the central government to change from being obliged to become voluntary plantation companies to implement this can cause corporate ignorance of the surrounding community, regulation contained in the plantation cluster in the Omnibus Law Employment Creation contradicts the old Plantation Law, Regional Government Law (Pemda Law), PPLH Law, and the 1945 Constitution of the Republic of Indonesia.

\section{Acknowledgements}

In this study, the authors would like to say to the Pembangunan Nasional Veteran University who have provided the opportunity for the author to contribute the results of this scientific thought, then the author also congratulates the parties who have helped the author to complete this research. This research is solely an attempt to research a legal problem and there is absolutely no conflict of interest against anyone in this research.

\section{References}

\section{Books}

Asshiddiqie, Jimly. (2015). Indonesian Constitution \& Constitutionalism. Second Edition. Jakarta: Sinar Grafika. 
Asshiddiqie, Jimly. (2015). Introduction to Constitutional Law. Jakarta: Rajawali Pers.

Daliyo, J.B., et.al. (2001). Introduction to Indonesian Law. Jakarta: Prenhallindo.

Garner, B. A. (Ed.). (2009). Black's Law Dictionary. Minnesota: West Publishing Co.

Harsono, B. (2008). Indonesian Agrarian Law. Revisited Edition. Jakarta: Djambatan.

Ishaq. (2017). Legal Research Methods and Writing Thesis, Thesis, and Dissertation. Bandung: Alfabeta.

Manullang, E. F. M. (2016). Legalism, Legality and Legal Certainty. Jakarta: Kencana Prenadamedia Group.

Marzuki, P. M. (2009). Legal Research. Jakarta: Kencana.

Purbacaraka, P., \& Soekanto, S. (1993). Regarding Legal Rule. Bandung: Citra Aditya Bakti.

Rosenfeld, M., \& Sajo A. (Ed.). (2012). The Oxford Handbook of Comparative Constitutional Law. United Kingdom: Oxford University Press.

Soekanto, S., \& Mamudji, S. (2001). Normative Legal Research A Brief Overview. Jakarta: PT Raja Grafindo Persada.

Sunggono, B. (1998). Legal Research Methodology. Jakarta: Raja Grafindo Persada.

Syarbani, S. \& Rusdiyanta (Ed.). (2010). Implementation of Pancasila through Citizenship Education. Yogyakarta: Graha Ilmu.

\section{Journal Articles}

Aedi, A. U., Lazuardi, S. \& Putri, D. C. (2020). Architecture of Application of Omnibus Law through Transplantation of National Laws of Law Establishment. Journal of Ilmiah Kebijakan Hukum. 14(1). 1-18

Agustira, M. A., Amalia, R. \& Nurkhoiry, R. (2015). Palm Oil Program for the People (Prowitra) as an Effort to Increase Productivity, Empowerment, Sustainability and Welfare of Smallholder Oil Palm Planters, Proceeding National Seminar "Perlindungan dan Pemberdayaan Pertanian dalam Rangka Pencapaian Kemandirian Pangan Nasional dan Peningkatan Kesejahteraan Petani". 315-324

Alexy, R. (2015). Legal Certainty and Correctness. Ratio Juris. 28(4). 441-451

Anggraeni, Ricca. \& Rachman, C. I. L. (2020). Omnibus Law in Indonesia: Is That the Right Strategy? Advances in Economics, Business and Management Research. 140. 180-182

Benuf, K. \& Azhar, M. (2020). Legal Research Methodology as an Instrument for Unraveling Contempore Legal Problems. Journal of Gema Keadilan. 7(1). 20-33

Braithwaite, J. (2002). Rules and Principles: A Theory of Legal Certainty. SSRN Electronic Journal.

Christiawan, R. (2020). Evaluation of the Moratorium Policy on Postponing the Issuance of Permits on Oil Palm Plantations. Journal of Veritas et Justitia. 6(1). 1-22. 
Dharmawan, A. H., et. al. (2019). Readiness of Independent Oil Palm Smallholders in Implementing ISPO: Environmental Issues, Legality and Sustainability. Journal of Ilmu Lingkungan. 17(2). 304-315

Erman, E. (2017). Behind Palm Oil Sustainability: Actors, Alliance in European Union Certification Political Economy. Masyarakat Indonesia, Journal of Ilmu-ilmu Sosial Indonesia. 43(1). 1-13

Eryan, A. (2019). From the Presidential Instruction for the Moratorium on Palm Oil to the Policy on Governance for the Palm Oil Industry, President Jokowi: A Case Study of the Issuance of Decree on the Release of PT Hardaya Inti Plantations in Buol, Central Sulawesi. Journal of Hukum Lingkungan Indonesia. 6(1). 1-18

Gluck, A. R., O'Connell, A. J., Po, R. (2015). Unorthodox Lawmaking, Unorthodox Rulemaking. Columbia Law Review. 115(7). 1789-1866

Hasibuan, S., \& Thaheer, H. (2017). Life Cycle Impact Assessment of Palm Biodiesel Production to Support the Sustainable Down Streaming of the Indonesian Palm Oil Industry, Proceeding National Seminar of Inovasi dan Aplikasi Teknologi di Industri. C47.1-7

Hastuti, D. (2021). Agrarian Policy Problems in the Omnibus Law Employment Creation on the Performance of Agrarian Reform in Indonesia. Papers of IAIN Jember Lecturers at the Lecturer Periodic Discussion Seminar. 1-16

Hutabarat, S. (2017). Challenges for the Sustainability of Smallholder Oil Palm Planters in Pelalawan District, Riau in Changing Global Trade. 43(1). Masyarakat Indonesia, Journal of Ilmu-ilmu Sosial Indonesia. 47-64

Indrapraja, F. M. (2018). Analysis of the Certification of Sustainable Palm Oil as an Instrument for Organizing Environmental Laws. Journal of Hukum Lingkungan. 4(2). 47-76

Khatun, R., et. al. (2017). Sustainable oil palm industry: The possibilities. Renewable and Sustainable Energy Reviews. 76. 608-619

Leawoods, H. (2000). Gustav Radbruch: An Extraordinary Legal Philosopher. Washington University Journal of Law E Policy. 2. 489-515

Massicotte, L. (2013). Omnibus Bills in Theory and Practice. anadian Parliamentary Review. 36(1). 13-17

Moho, H. (2019). Law Enforcement in Indonesia according to the Aspects of Legal Certainty, Justice and Benefit. Journal of Warta Dharmawangsa. 13(1).

Muamar \& Utari, A. A. S. (2020). The Effect of the Elimination of the Principle of Strict Liability in the Omnibus Law Employment Creation on Massive Deforestation in Indonesia. Journal of Kerta Negara. 8(12). 1-12.

Ngadi \& Noveria, M. (2017). Sustainability of Oil Palm Plantations in Indonesia and Development Prospects in Border Areas, Indonesian Communities. Masyarakat Indonesia, Journal of Ilmu-ilmu Sosial Indonesia. 43(1). 95-111

Schofield, P. (2013). The Legal and Political Legacy of Jeremy Bentham. Annual Review of Law and Social Science. 9(1).

Wilcove, D. S., \& Koh, L. P. (2010). Addressing the Threats to Biodiversity from Oil-palm Agriculture. Biodiversity and Conservation. 19(4). 999-1007. 


\section{Website Material}

American Chamber of Commerce in Indonesia. (2020). Omnibus Bills: How do they Work? Retrieved February 11, 2021 from https:/ / www.amcham.or.id / omnibus-bills-how-do-they-work

BBC News Indonesia. (2020). The contents of the Omnibus Law: The final document of the Job Creation Law cannot yet be accessed by the public, experts are worried about "the entry of contraband articles". Retrieved February 11, 2021, from https://www.bbc.com/indonesia/Undang-Undang-Omnibus-LawCipta-Kerja

Detik Finance. (2020). 3 Impact of the Foreign Analyst version of the Omnibus Law on Job Creation. Retrieved February 11, 2021 from https:/ / finance.detik.com/berita-ekonomi-bisnis/ 3-dampak-omnibuslaw-cipta-kerja-versi-analis-asing.

Gatra.com. Aziz, A. (Ed.). (2020). Omnibus Law Ratified, Happy Palm Oil Farmers. Retrieved February 11, 2021, from https://www.gatra.com/ omnibus-law-disahkan-petani-sawit-sumringah.

Guru Pendidikan. (2021). Legal Research Methods, Understanding, Kinds, Normative, Empirical, Approaches, Data, Analysis, Experts. Retrieved February 12, 2021, from https://www.gurupendidikan.co.id/metodepenelitian-hukum

Hukum Online. (2020). Get to know the "Omnibus Law" method. Retrieved February 11, 2021, from https://www.hukumonline.com/mengenalmetode-omnibus-law

Info Sawit. (2020). Improved Governance of Palm Oil "lousy" Due to the Omnibus Law Employment Creation. Retrieved February 11, 2021, from https:/www.infosawit.com/perbaikan-tata-kelola-sawit-runyamakibat-ciptaker

Kadin Indonesia. (2020). The Palm Oil Industry Embraces the Implementation of Omnibus Law. Retrieved February 11, 2021, from https:/ / kadin.id/kelapa-sawit-sambut-positif-penerapan-omnibus-law

Kompas. (2020). Dissecting Concerns about Tenure of Palm Oil in the Job Creation Law. Retrieved February 11, 2021, from https:/ / money.kompas.com/membedah-kekhawatiran-penguasaanlahan-sawit-di-uu-cipta-kerja

Mongabay. (2020). Omnibus Law 'Smooth Road' Legalizes Oil Palm Investment Violations in Forest Areas? Retrieved February 11, 2021, from www.mongabay.co.id/omnibus-law-jalan-mulus-legalkanpelanggaran-investasi -sawit-dalam-kawasan-hutan

Tribun Palu. (2020). President Jokowi Describes 6 Positive Impacts of the Omnibus Law on Work for the Business and Investment Climate. Retrieved November 20, 2020, from https://palu.tribunnews.com/presiden-jokowi-uraikan6-dampak-positif-omnibus-law-cipta-kerja-bagi-iklim-usaha-daninvestasi

\section{Magazine Articles}


Corley, R.H.V. (2009, April). How much palm oil do we need? Environmental Science \& Policy. 12(2). 134-139

Petrenko, C., Paltseva, J., Searle, S. (2016, July). Ecological Impacts of Palm Oil Expansion in Indonesia. White Paper, The International Council on Clean Transportation.

\section{Law \& Regulation}

Academic Paper on Omnibus Bill Employment Creation.

Constitution of the Republic of Indonesia 1945.

Law of the Republic of Indonesia, Number 11 Year 2020 concerning Job Creation, State Gazette of the Republic of Indonesia Year 2020 Number 245, Supplement to State Gazette of the Republic of Indonesia Number 6573.

Law of the Republic of Indonesia, Number 23 Year 2014 concerning Regional Government, State Gazette of the Republic of Indonesia Year 2014 Number 244, Supplement to the State Gazette of the Republic of Indonesia Number 5587.

Law of the Republic of Indonesia, Number 25 Year 2007 concerning Investment, State Gazette of the Republic of Indonesia Year 2007 Number 67, Supplement to the State Gazette of the Republic of Indonesia Number 4724.

Law of the Republic of Indonesia, Number 32 Year 2009 concerning Protection and Management of the Environment, State Gazette of the Republic of Indonesia Year 2009 Number 140, Supplement to the State Gazette of the Republic of Indonesia Number 5059.

Law of the Republic of Indonesia, Number 39 Year 2014 concerning Plantations, State Gazette of the Republic of Indonesia Year 2014 Number 308, Supplement to the State Gazette of the Republic of Indonesia Number 5613. 